SHS Web of Conferences 12, 01097 (2014)

DOI: $10.1051 /$ shsconf/ 20141201097

(C) Owned by the authors, published by EDP Sciences, 2014

\title{
Rural Tourism at its Peak: Socio-Cultural Impacts towards Host Communities of Kinabalu Park, Sabah (Malaysian- Borneo)
}

\author{
Tania Maria Tangit ${ }^{1}$, Ahmad Khairuman Md Hasim², Akmal Adanan ${ }^{3}$ \\ ${ }^{1}$ Faculty of Hotel \& Tourism Management, Universiti Teknologi MARA, Sabah, Malaysia \\ ${ }^{2,3}$ Faculty of Hotel \& Tourism Management, Universiti Teknologi MARA, Melaka, Malaysia
}

\begin{abstract}
The Kinabalu Park in Sabah (Malaysian-Borneo) represents multiple tourism opportunities for its stakeholders, host communities and tourists. Being the first World Heritage Site in Malaysia endorsed by UNESCO since 2000, this nature-based tourism destination is a popular tourism destination in Malaysia, as well as in the Asia region. The designated study area includes villages nearby Kinabalu Park. Through the popularity of the park and various other attractions within the area, tourism activities contributes to socio-cultural impacts towards its host communities. The perceptions and attitudes of the locals towards tourism are identified and evaluated. By having the input of host communities as part of conserving tourism whilst meeting certain principles of sustainable tourism, the paper aims to attain interesting findings about the perceptions of the host communities towards socio-cultural impacts of tourism on their community. The paper further aims to recommend for the continuous improvement of sustainable tourism development at Kinabalu Park and its surroundings.
\end{abstract}

\section{Introduction}

It should be pointed out that the people of Sabah are divided into 32 officially recognised ethnic groups, where the largest indigenous ethnic group is Kadazandusun (17.8\%) and predominantly wet rice and hill cultivators [1]. Ranau, a rural district of Sabah, has a total population of 94,092 people and with slightly more than $85 \%$ are of the Kadazandusun tribe [2]. Located in Ranau, Kinabalu Park covers an area of $754 \mathrm{sq} \mathrm{km}$ and was gazetted as a park in 1964 [3-4]. The park houses Mount Kinabalu, which stands amidst 4095 meters above sea level. It also comprises of Poring Hot Springs, Mesilau, and sub-stations located at the district of Kota Belud and Kota Marudu. The Kadazandusun community reveres Mount Kinabalu as the ancient belief is that 'Nabalu' means "place of spirits of the dead" [5].

Sabah Parks, the main caretaker for the mountain, the park and its surroundings, aims to protect, conserve and preserve natural areas of Sabah Parks, especially areas which contains unique features with high aesthetical values as a natural heritage, so that it remains preserved for the benefit, knowledge, scientific researches and recreational sites for the present and future generations [4]. The Ministry of Tourism, Culture and Environment, the Wildlife Department, Environment Protection Department, Sabah Cultural Board as well as Sabah Tourism Board are other main stakeholders of Kinabalu Park. 
As Malaysia's first World Heritage Site and a popular destination, the number of visitors to Kinabalu Park (including from various sub-stations) for the year 2012 is 715,927 visitors, where almost $40 \%$ of the total visited the park headquarters [4]. Nonetheless, in the following year, there has been a decrease of $27 \%$ on the total number of visitors $(519,913$ visitors) to the park. However, gathered from the Sabah Tourism Website (2014) [4], the total number of tourist arrivals to Sabah showed a $17.6 \%$ increase in 2013 from the total of 2,875,761 visitors from the previous year. With an increase of tourist arrivals to Sabah as a whole and a decrease of visitors to the park, there is a need to study on the possible socio-cultural impacts host communities whom are affected with the tourism developments as of the case of Kinabalu Park and its nearby surroundings.

The aim of this study is to identify the socio-cultural impacts of the tourism industry towards the host communities of Kinabalu Park and its surroundings. The objectives of this exploratory research are to identify different socio-cultural impacts of tourism, and to evaluate the socio-cultural impacts of tourism. It is imperative to understand how host communities perceive socio-cultural impacts of tourism, which affects them, in order for stakeholders to have insights on how the locals balance these issues in their daily lives.

\section{Empirical Study}

A review of the literature saw three main areas of study, which are host communities, sustainable tourism in rural areas and tourism impacts, particularly socio-cultural impacts. A summary of the following is presented.

\subsection{Defining host communities}

Host communities are a vital element in the success of tourist destinations, sustainable tourism is dependent upon the willingness of the host community to service tourists [6]. Swarbrooke "all those people who live within a tourist destination" [7]. For the purpose of this study, the study population is targeted to the people who live within the tourist destination (Kinabalu Park and its surroundings) regardless whether they are directly or indirectly affected by the tourism industry.

\subsection{Sustainable tourism in rural areas}

Sustainable tourism is an important concept in the tourism field. UNWTO website (n.d.) in UNEP and UNWTO (2005:11-12) [8] defined sustainable tourism as "tourism that takes full account of its current and future economic, social and environmental impacts, addressing the needs of visitors, the industry, the environment and host communities". From a tourism standpoint, sustainability principles refer to the environmental, economic and socio-cultural aspects of tourism development, and a suitable balance must be established between these three dimensions to guarantee its long-term sustainability [9]. Aspinall (2006) [10] too affirms the three common components when measuring sustainability, which are economic, social and environment.

UNESCO (2004) defines sustainable tourism as "tourism that respects both local people and the traveller, cultural heritage and the environment". Host communities are often the weaker party in interaction with guests and service providers [11]. The socio-cultural impacts of tourism can be both negative and positive [7]. Therefore, appropriate planning can help to prevent the negative sociocultural impacts from affecting the host population [12-13.

In reference to defining "rural areas", authors Shaw and William (1994) [14] describe rural areas as idyllic places to escape from the pressure of modern urban-industrial life in which for some to rekindle the human spirit. Lane (1994) [15] suggests that, rural tourism should be functionally rural, small in scale, traditional in character, organically and slowly growing and controlled by the local people, apart from being located in rural areas. Further stated, rural tourism extends beyond farmbased tourism to include special-interest nature holidays and ecotourism, walking, climbing and riding holidays, adventure, sport and health tourism, hunting and angling, educational travel, arts and 
heritage tourism, and in some areas, ethnic tourism (Lane, 1994:9) [15]. This description is applicable to the case of Kinabalu Park and its surroundings where the main product would be Mount Kinabalu itself. Hence, this study takes the definition of rural tourism from the Organization for Economic Cooperation and Development (OECD, 1994) [16], as any "tourism taking place in the countryside".

\subsection{Socio-cultural impacts at tourism destinations}

Murphy (1985) [17] defines tourism as a socio-cultural event for both the guest and host. Described in UNEP website (n.d.) [11], socio-cultural impacts of tourism are the effects on host communities of direct and indirect relations with tourists, and of interaction with the tourism industry. These impacts can bring changes in value systems and behaviours, hence threatening indigenous identity. Nonetheless, impacts on tourism can be positive and seen when fostering pride in cultural traditions and help avoid urban relocation by creating local jobs.

The socio-cultural impacts of tourism are basically consequences of either the development of the tourism industry or the presence of the tourists (and the characteristics of the tourist-host relationship) (Sharpley, 1994) [18]. Fox (1977) [19] suggests that the social and cultural impact of tourism is the way in which tourism contributes to the change in value systems, individual behaviour, family relationships, and collective lifestyles, levels of security, moral conduct, creative expressions, traditional ceremonies and community organizations. Also supported, by Smith (1995) [20] who states that the interaction between host and guest qualifies as a socio-cultural impact.

The relationship between the impacts of tourism and residents' attitudes toward tourism was studied by various research and several models and theories were developed. One of the most influential models is Doxey's Irridex Model (1975) [21], which is a theoretical model that states an increase in numbers of tourists and a more developed tourism industry at the destination results in irritation in the host community. In other words, the more developed tourism industry is at a particular area, local community may be irritated and resent tourism as to show incompatibility of the host and the guest.

\section{Methodology}

Exploratory and conclusive research designs were applied for this research. Secondary data were derived from the District Office of Ranau, where the village population and demographic profiles were considered vital internal sources for this study. For the purpose of this study, the study population is targeted to the people who live within the tourist destination (Kinabalu Park and its surroundings) regardless whether they are directly or indirectly affected by the tourism industry. Convenience sampling was applied and conducted within 6 main villages of the district, namely, Bundu Tuhan, Kundasang, Kinasaraban, Mesilau, Poring and Luanti Baru.

The survey was conducted in November 2012 where the sampling population was specifically chosen for reasons being, (1) The main workforce of Kinabalu Park and supporting services within the park are from the villages within the selected sub-districts, and, (2) The sub-districts are closest to Kinabalu Park, the area of study. These villages were selected according to its location and the available tourist attractions within the area. A sample of 378 respondents was gathered from various villages within the sub-districts of Kundasang and Bundu Tuhan.

The framework and indicators for this study is adapted from Alhasanat and Hyasat (2011) [22]. A compilation items were given a five-point Likert-type response format based on the following scale; $1=$ strongly disagree, $2=$ disagree, $3=$ neutral, $4=$ agree, and $5=$ strongly agree.

\section{Analysis and findings}

The results of the analyses show the samples' mean responses and standard deviation in answering the research objectives of this study. The analyses are divided into two sections; descriptive respondents' 
demographic profile and a descriptive analysis on respondents' perceptions on socio-cultural impacts of tourism.

\subsection{Demographic PROFILE}

The respondents $(\mathrm{n}=378)$ for this study were local $(88.6 \%)$, female $(61.4 \%)$ between the ages of $21-30$ years old (31.5\%) and 31-40 years old (24.3\%). As shown in Table 1, more than half of the respondents attended secondary school (54.2\%) and a quarter had attended tertiary education (25.1\%). There are $68.3 \%$ of the respondents whom are involved in the tourism industry and almost $50 \%$ of the respondents have been involved in the tourism industry between 1-10 years. They are attached at various sectors within the tourism industry such as agriculture $(18.5 \%)$ and entrepreneurs $(20.6 \%)$.

Table 1. Perceptions of respondents towards socio-cultural impacts of tourism

\begin{tabular}{|c|c|c|c|}
\hline \multicolumn{2}{|l|}{ Demographic Profile } & Frequency & Percentage \\
\hline \multirow{2}{*}{ Gender } & Male & 146 & 38.6 \\
\hline & Female & 232 & 61.4 \\
\hline \multirow{5}{*}{ Age Group } & $18-20$ & 23 & 6.1 \\
\hline & $21-30$ & 119 & 31.5 \\
\hline & $31-40$ & 92 & 24.3 \\
\hline & $41-50$ & 78 & 20.6 \\
\hline & 50 and above & 66 & 17.5 \\
\hline \multirow{5}{*}{ Education } & No Formal Education & 26 & 6.9 \\
\hline & Primary School & 52 & 13.8 \\
\hline & Secondary School & 205 & 54.2 \\
\hline & Certificate / Diploma & 72 & 19.0 \\
\hline & Degree & 23 & 6.1 \\
\hline \multirow{2}{*}{ Local of Ranau } & Yes & 335 & 88.6 \\
\hline & No & 43 & 11.4 \\
\hline \multirow{2}{*}{ Involvement in Tourism } & Yes & 258 & 68.3 \\
\hline & No & 120 & 31.7 \\
\hline \multirow{9}{*}{ Years involved in Tourism } & $1-3$ years & 75 & 19.8 \\
\hline & $4-6$ years & 56 & 14.8 \\
\hline & $7-10$ years & 58 & 15.3 \\
\hline & $11-15$ years & 16 & 4.2 \\
\hline & $16-20$ years & 14 & 3.7 \\
\hline & $21-30$ years & 13 & 3.4 \\
\hline & More than 31 years & 4 & 1.1 \\
\hline & No Response & 22 & 5.8 \\
\hline & Not Applicable & 120 & 31.7 \\
\hline \multirow{6}{*}{ Occupation } & Farmer / Agriculture & 71 & 18.8 \\
\hline & Business / Entrepreneur & 80 & 21.2 \\
\hline & Government Employee & 25 & 6.6 \\
\hline & Others & 57 & 15.1 \\
\hline & No Response & 25 & 6.6 \\
\hline & Not Applicable & 120 & 31.7 \\
\hline
\end{tabular}

\subsection{Results of descriptive analyses}

The main objective of this study is to identify different socio-cultural impacts of tourism and to evaluate them. Hence, the following analysis looks into investigating the socio-cultural impacts of tourism from the perspectives of the host communities of Kinabalu Park and its surrounding areas. The responses of the study population (measured by Mean and Standard Deviation) are perceptions of 
respondents towards the impacts of tourism, which can be measured by both positive and negative impacts as elaborated in Table 2 .

Table 2. Perceptions of respondents towards socio-cultural impacts of tourism

\begin{tabular}{|c|c|c|}
\hline Statements & Mean & S.D. \\
\hline \multicolumn{3}{|l|}{ Perceptions towards the impact of Tourism } \\
\hline Tourism has improved the image of Kinabalu Park and its surrounding areas & 4.23 & 0.804 \\
\hline $\begin{array}{l}\text { Due to tourism, infrastructure at Kinabalu Park and its surrounding areas has been enhanced such } \\
\text { as roads, hospitals, schools, etc }\end{array}$ & 3.90 & 1.019 \\
\hline Tourism increases the level of education at Kinabalu Park and its surrounding areas & 3.77 & 0.850 \\
\hline Tourism has improved my behaviours with my family and society & 3.65 & 0.939 \\
\hline $\begin{array}{l}\text { Tourism encourages immoral behaviours of some people at Kinabalu Park and its surrounding } \\
\text { areas }\end{array}$ & 2.28 & 1.157 \\
\hline Tourism has increased crime in the local community at Kinabalu Park and its surrounding areas & 1.99 & 1.035 \\
\hline Tourism is the reason of sor & 2.06 & 1.060 \\
\hline Benefits of tourism at Kinabalu Park and its surrounding areas outweigh its costs & 2.84 & 0.983 \\
\hline \multicolumn{3}{|l|}{ Perceptions towards the impacts of exposure to tourist activities } \\
\hline I benefit from tourism at Kinabalu Park and its surrounding areas & 3.71 & 0.915 \\
\hline Tourism at Kinabalu Park and its surrounding & 3.77 & 0.882 \\
\hline I support tourism & 4.02 & 1.013 \\
\hline Women are not suitable to work in the tourism industry & 2.03 & 1.229 \\
\hline $\begin{array}{l}\text { The closer my residency to the tourist site the more I benefit out of tourism at Kinabalu Park and } \\
\text { its surrounding areas }\end{array}$ & 3.65 & 1.108 \\
\hline Tourism increased the cost of living at Kinabalu Park and its surrounding areas & 3.32 & 1.063 \\
\hline $\begin{array}{l}\text { I have more money to spend because of my work in tourism at Kinabalu Park and its surrounding } \\
\text { areas }\end{array}$ & 3.08 & 1.160 \\
\hline I deal with tourist almost every day & 3.27 & 1.266 \\
\hline Earnings from tourism lure children in my community to drop out of school at an early age. & 2.29 & 1.163 \\
\hline \multicolumn{3}{|l|}{ Perceptions according to seasonality, cultural differences between host and guests } \\
\hline Tourism during high season contributes to issues such as crowding, inflation, etc & 2.86 & 1.118 \\
\hline $\begin{array}{l}\text { Working in tourism during high season is feasible, though I prefer having a permanent job in } \\
\text { another sector }\end{array}$ & 3.26 & 1.056 \\
\hline I interact with individual tourist more than I do with tourists in groups & 3.07 & 1.177 \\
\hline id traditions & 3.97 & 0.836 \\
\hline Tourism made me understand other cultures better & 4.06 & 0.784 \\
\hline Tourism increased my pride in our national culture & 4.22 & 0.778 \\
\hline I encourage more tourists to come and see Kinabalu Park and its surrounding areas & 4.26 & 0.864 \\
\hline $\begin{array}{l}\text { I support tourism development in Kinabalu Park and its surrounding areas concerning more } \\
\text { marketing and in site infrastructure }\end{array}$ & 4.16 & 0.837 \\
\hline $\begin{array}{l}\text { Community representatives at Kinabalu Park and its surrounding areas are involved in } \\
\text { development decisions concerning Kundasang }\end{array}$ & 3.71 & 1.062 \\
\hline Negative impacts of tourism may drive me to leave Kinabalu Park and its surrounding are & 2.03 & 1.268 \\
\hline
\end{tabular}

Note: $\mathrm{n}=378$, S.D. $=$ Standard Deviation

Respondents perceive tourism to improve the image of Kinabalu Park and its surrounding areas $(\mathrm{m}=4.23)$, increase the level of education $(\mathrm{m}=3.77)$ and infrastructure has improved due to tourism $(\mathrm{m}=3.90)$. The study attempts to also identify the impacts of respondents' exposure to tourist activities. Generally, respondents support tourism and welcome tourists to their community $(\mathrm{m}=4.02)$. They also feel that tourism improves their lifestyle $(\mathrm{m}=3.77)$ and they benefit from tourism $(\mathrm{m}=3.71)$. Respondents' felt indifferent on having more money to spend although working in tourism field $(\mathrm{m}=3.08)$ as well as the increase of cost of living $(\mathrm{m}=3.32)$. Not all respondents deal with tourists everyday $(\mathrm{m}=3.27)$, nonetheless, they feel the closer they live near a tourist site, the more benefits they get out of tourism $(\mathrm{m}=3.65)$.

On respondents' perceptions of tourism according to its seasonality and cultural differences, they feel that tourism led them to understand other cultures' better $(m=4.06)$, increase pride in national 
culture $(\mathrm{m}=4.22)$, hence, encourage more tourists to come and see Kinabalu Park and its surrounding areas $(\mathrm{m}=4.26)$. They support tourism development when it comes to marketing their area as well as the provision of in-site infrastructures $(\mathrm{m}=4.16)$ and somewhat agree that community representatives are involved in development decisions $(\mathrm{m}=3.71)$. However, respondents disagreed that negative impacts of tourism may drive them to leave Kinabalu Park and its surrounding areas $(\mathrm{m}=2.03)$ although tourism during high season contributes to issues such as crowding, inflation, etc $(\mathrm{m}=2.86)$.

Both descriptive and analytical data results were interpreted to obtain findings about the perceptions of the host communities of Kinabalu Park and its surrounding areas on tourism development. It was derived that not all negative socio-cultural impacts particularly on crime rates $(\mathrm{m}=1.99)$, immoral behaviors $(\mathrm{m}=2.28)$ and misbehaviours $(\mathrm{m}=2.06)$ are directly associated with the host community. Residents who are directly employed in tourism tend to be more tolerant of the impacts (Faulkner and Tideswell, 1997) [23]. It is interesting to note that respondents perceive women to be unsuitable to work in the tourism industry $(\mathrm{m}=2.03)$. This supports the findings by Swarbrooke (1999) [7] in a similar study in Tunisia that men occupied most of the jobs in tourism. Nonetheless, residents do feel quite indifferent on the benefits of tourism in outweighing its costs $(\mathrm{m}=2.84)$.

\section{Conclusion and Recommendations}

Mount Kinabalu, located in Kinabalu Park, Kundasang, serves as an intangible cultural heritage for the Kadazandusun communities of Sabah as they believe that the mountain is the final resting place for departed souls. As Mount Kinabalu is an important asset to the Kadazandusun community, and Sabahan and Malaysians as a whole, it is vital that socio-cultural impacts of the host communities of Kinabalu Park and its surroundings are minimized and controlled.

The overall result of this study is consistent with the literature presented and it concludes that not all tourism activities are welcomed at Kinabalu Park and its surrounding areas as there are negative socio-cultural impacts, which could deteriorate the host community's social structure and cultural traditions. Generally, respondents are still receptive in receiving tourists and welcoming tourism developments in Kinabalu Park and its surrounding areas, although, responses gained were not surprisingly high (i.e. tourists show respect to our culture and traditions $(\mathrm{m}=3.97)$, tourism increased my pride in our national culture $(\mathrm{m}=4.22)$, I encourage more tourists to come and see Kinabalu Park and its surrounding areas $(\mathrm{m}=4.26)$, etc). This supports the opinions of Allen, Long, Perdue and Kieselbach (1988) [24] who found that tourism is often considered beneficial in areas of lower to moderate levels of development.

In relation to Doxey's Irridex, the attitudes of the host communities of Kinabalu Park and its surrounding areas and its surroundings towards tourism development are between euphoria and apathy. The result of this study does not represent any obvious irritations towards tourism development; hence, tourism in Kinabalu Park and its surrounding areas are still being welcomed. However, to maintain tourism development at a controllable level, Faulkner and Tideswell (1997) [23] states that the socio-cultural impacts of tourism should be monitored continuously in order to maximize the benefits of tourism at the destination.

From a resource management point of view, social and cultural impacts of tourism should be considered throughout the planning process and in an environmental impact assessment procedure, so that benefits are optimized and problems minimized (Brunt, 1999) [25]. Therefore, the study has met its objectives in investigating the host communities' overall perception on socio-cultural impacts of tourism at Kinabalu Park and its surrounding areas. The findings of this investigation can assist tourism stakeholders especially government agencies as well as tourism planners in the implementation of sustainable tourism development strategies based on the input of the host communities when making decisions involving tourism at Kinabalu Park and its surrounding areas. 


\section{Acknowledgements}

The funding for this project is made possible through the research grant obtained from the Ministry of Higher Education, Malaysia under the Long Term Research Grant Scheme 2011 [LRGS grant no: JPT.S (BPKI)2000/09/01/015Jld.4(67)]. This research is also made possible with the assistance from Universiti Teknologi MARA, Malaysia, the Ministry of Culture, Environment and Tourism of Sabah and its agencies, Sabah Parks, Sabah Tourism Board, Sabah Cultural Board and the Environment Protection Department of Sabah.

\section{References}

1. Sabah Tourist Association Website, 2014. People \& Culture. Accessed on $10^{\text {th }}$ March 2014 from URL: http://www.sta.my/people_culture.cfm (2014)

2. Population and Housing Census of Malaysia, 2014. Population in Malaysia based on Ethnic. Accessed on $10^{\text {th }}$ March 2014 from URL:

http://www.statistics.gov.my/portal/download_Population/files/population/04Jadual_PBT_negeri/ PBT_Sabah.pdf(2014)

3. UNESCO, 2014. Kinabalu Park. Accessed on $10^{\text {th }}$ March 2014 from URL: http://whc.unesco.org/en/list/1012 (2014)

4. Sabah Parks, 2014. Introduction - Kinabalu Park. Accessed on $10^{\text {th }}$ March 2014 from URL: http://sabahparks.org.my/eng/kinabalu_park/ (2014)

5. Kadazandusun Cultural Association, 2005. Kinabalu: Kina Balu, Aki Nabalu or Ki Nabalu. Accessed on $10^{\text {th }}$ March 2014 from URL: http://kdca.org.my/archives/68 (2005)

6. K. Kim, The Effects of Tourism Impacts on Quality of Life of The Residents In The Community. Unpublished doctoral dissertation, Virginia Polytechnic Institute and State University (2002)

7. J. Swarbrooke, The Host Community (11:123). Sustainable Tourism Management Wallingford: CABI Publishing (1999)

8. UNWTO, n.d. Definition of Sustainable Tourism in Making Tourism More Sustainable - A Guide for Policy Makers, UNEP and UNWTO, Accessed on 20th March 2014 from URL: http://sdt.unwto.org/content/about-us-5 , 11-12 (2005)

9. UNWTO, in European Centre for Ecological and Agricultural Tourism (2004)

10. A.J. Aspinall, Communities in change: social sustainability and tourism development. Unpublished master's thesis, University of Waterloo, Ontario, Canada. (2006)

11. UNEP, n.d. Socio-Cultural Impacts of Tourism. Accessed on 22nd April 2014 from URL: http://www.unep.org/resourceefficiency/Home/Business/SectoralActivities/Tourism/WhyTourism /ImpactsofTourism/SocioCulturalImpacts/tabid/78780/Default.aspx

12. UNESCO, Sustainable Tourism. Accessed on 22nd April 2014 from URL : http://www.unesco.org/education/tlsf/mods/theme_c/mod16.html (2007)

13. UNWTO, n.d. Sustainable Development of Tourism - Definition. Accessed on 16th May 2014 from URL : http://sdt.unwto.org/content/about-us-5

14. G. Shaw and A. Williams. Critical issues in tourism. Oxford: Blackwelln. (1994)

15. B. Lane, What is rural tourism?. Journal of Sustainable Tourism, ISSN 0966-9582, 2, 1-2, 7-21 (1994)

16. OECD. Tourism policy and international tourism in OECD countries 1991-1992, Organization for Economic Co-Operation and Development, ISBN 9-26414-091-3, Paris, France (1994)

17. P.E. Murphy, Tourism: A Community Approach. London: Routledge (1985)

18. R. Sharpley, Tourism, Tourists and Society. Huntingdon: ELM (1994)

19. M. Fox, The Social Impacts of Tourism: a Challenge to researchers and planners, University of California: Santa Cruz (1977)

20. S.L.J. Smith, Tourism Analysis. Harlow: Longman (1995) 
21. G.V. Doxey, A causation theory of visitor-resident irritants: methodology and research inferences, Proceedings of the Travel Research Association, 6th Annual Conference, San Diego, California, USA, 195-8 (1975)

22. S.A. Alhasanat and A.S. Hyasat. Sociocultural Impacts of Tourism on the Local Community in Petra, Jordan. Jordan Journal of Social Sciences, 4, 1, 2011

23. B. Faulkner \& C. Tideswell, 'A framework for monitoring community impacts of tourism', Journal of Sustainable Tourism, 5, 1, 3-28 (1997)

24. R.P. Allen, R. Long, Perdue, and S. Kieselbach, The Impact of Tourism Development on Residents' Perceptions of Community Life. Journal of Travel Research 27, 1, $16-21$ (1988)

25. P. Brunt and P. Courtney. Host Perceptions of Sociocultural Impacts. Annals of Tourism Study, 26, 3, 493-515 (1999)

26. Sabah Parks, Introduction (History of Establishment). Accessed on $10^{\text {th }}$ March 2014 from URL: http://sabahparks.org.my/eng/public/02introduction.asp (2014)

27. Sabah Parks, Visitor Statistics. Accessed on $10^{\text {th }}$ March 2014 from URL: http://sabahparks.org.my/eng/public/visitorfigure.asp (2014)

28. Sabah Tourism, Visitor Statistics. Accessed on $10^{\text {th }}$ March 2014 from URL: http://www.sabahtourism.com/business/statistic (2014) 